\title{
28. Összegzés - A koronavírus-járvány kezelésének tapasztalatai a vizsgált államokban
}

\section{HOJNYÁK DÁVID - UNGVÁRI ÁLMOS}

A világ országainak koronavírus-járvány okozta egészségügyi válsághelyzetre adott válaszát egymás mellé állítva - különböző vizsgálódási szempontok alapján, illetve más-más államok szabályozását elemezve - a hazai ${ }^{1}$ és külföldi² szakirodalom egyaránt vizsgálja, de az Európai Unió tagállamainak járványkezelésével ${ }^{3}$ is foglalkozott már a jogirodalom.

Jelen fejezetben a könyváltal tárgyalt országok szabályozását foglaljuk össze. Rögzítjük, hogy mely országokban rendeltek el különleges jogrendi állapotot, illetve azt - a nemzeti jogszabályok adta kereteknek megfelelően - milyen időbeli hatállyal hirdették ki. Emellett elemzésre kerül,

1 Lásd például: Hojnyák-Ungvári, 2020, 122-138. o.; Hegedős-Karácsony-Monostori, 2020, 28-42. o.; Hojnyák-Ungvári, 2021.

2 Lásd például: Cameron-Jonsson Cornell, 2020, 1173-1190. o.; Golia-Hering-Moser-Sparks, 2020; Desmet, 2020, 79-88. o.; Guasti, 2020, 47-60. o.

3 Binder et al., 2020; Atanassov et al., 2020; Bentzen et al., 2020; Alexandre et al., 2020. Külön kiemelendő a Velencei Bizottság által kibocsátott jelentés, amely alkotmányjogi szempontból vizsgálja és értékeli az európai uniós tagállamok járványkezelési szabályozását a koronavírus-járvánnyal összefüggésben (Venice Commission, 2020).

Dr. Hojnyák Dávid

david.hojnyak@mfi.gov.hu

kutató (Mádl Ferenc Összehasonlító Jogi Intézet)

PhD-hallgató (Miskolci Egyetem, Deák Ferenc Állam- és Jogtudományi Doktori Iskola)

Dr. Ungvári Álmos

kutató (Mádl Ferenc Összehasonlító Jogi Intézet)

PhD-hallgató (Pázmány Péter Katolikus Egyetem, Jog- és Államtudományi Doktori Iskola)

Hojnyák, D., Ungvári Á. (2021) 'Összegzés - A koronavírus-járvány kezelésének tapasztalatai a vizsgált államokban' in Nagy, Z., Horváth, A. (szerk.) A különleges jogrend és nemzeti szabályozási modelljei, 610-623. o. Budapest: Mádl Ferenc Összehasonlító Jogi Intézet.

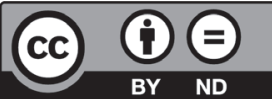


hogy a vizsgált országokban a gyors és hatékony válságintézkedések érdekében mely állami szereplők felhatalmazásával és milyen formában valósul meg a rendeleti kormányzás, illetve hogy annak vonatkozásában milyen mértékben és formában tudják ellenőrző funkciójukat ellátni az egyes államok törvényhozó szervei. Továbbá az alapjogok korlátozásának kérdésével is foglalkozik a fejezet, valamint utalás történik azokra a közjogi-politikai jellegű vitákra is, amelyek nemzeti szinten jelentkeztek a foganatosított kormányzati intézkedések nyomán. A fejezetben a vizsgált államok intézkedéseinek egymás melle állításával és elemzésével lehetőség nyílik a koronavírus-járvány kezelése érdekében alkalmazott nemzeti járványkezelési megoldások összehasonlítására, valamint ennek eredményeként különböző szabályozási modellek kialakítására.

\section{Különleges jogrend bevezetése a koronavírus-járvány kezelése érdekében}

A vizsgált államok koronavírus-járvány kezelésének jogszabályi keretei közti különbség leglátványosabban a különleges jogrendi állapot elrendelése, illetve annak hiánya vonatkozásában mutatkozik meg. A vizsgált országok alig fele alkalmazta a különleges jogrend eszközét, ráadásul - ahogyan arra jelen könyv korábbi fejezetei rámutatnak - annak nincsen általános sztenderdje, szabályozása számos ponton eltér. Így érdemes egyrészt egymás mellé állítani az államok által bevezetett különleges jogrendi szituációkat, másrészt pedig megvizsgálni azt, hogy azon országok esetében, ahol a koronavírus-járvány kezelése rendes jogrendi keretek között zajlott, mely ágazati jogszabályok kerültek alkalmazásra.

Magyarországhoz hasonlóan Csehországban, Szlovákiában, az Egyesült Királyságban, Finnországban, Lettországban, Romániában és Spanyolországban egyaránt különleges jogrendet vezettek be. Azonban hiába képezte a különleges jogrend bevezetésének alapját ugyanaz a humánjárvány, az elrendelt kategóriák, illetve azok elnevezése nem azonos. Így például Magyarország mellett Szlovákia és Lettország is veszélyhelyzetet hirdetett, Csehország és Finnország szükségállapotot vezetett be, Spanyolországban pedig riadókészültséget rendeltek el. A járványhelyzetre válaszul Románia sürgősségi állapotot rendelt el, ám még a tavasz végén - a koronavírus-járvány leküzdésének sajátos szabályait rögzítő törvényben - új alapokra helyezte a válságkezelés jogszabályi kereteit. A sürgősségi állapot fenntartása helyett riadóállapotot léptettek életbe, amely egy ideiglenes, többek között az életet és az egészséget fenyegető veszélyek megelőzésére és elhárítására irányuló, a különleges helyzet jelenlegi és jövőbeli súlyosságával arányos rendkívüli intézkedésrendszer. Ezektől eltérő megoldást alkalmazott az Egyesült Királyság, ahol törvényi úton hirdettek ki egy újfajta, speciálisan a koronavírus-járvány kezelésére megalkotott - a járvány kezelésének megkönnyítését és terjedésének lassítását, az állami szervek múködésének biztosítását és a gazdaság múködőképességének megőrzését célzó - kivételes jogrendi állapotot. 
A törvény időbeli hatálya meghatározott időre, fôszabály szerint két évre szól, ám annak fél évvel történő meghosszabbítására és lerövidítésére is lehetőség van.

Ez utóbbi vonatkozásában is jelentősen eltér a többi állam által bevezetett különleges jogrendi állapottól az Egyesült Királyság járványkezelése. A többi vizsgált ország ugyanis rövidebb határidôt jelölt meg, és azt hosszabbította meg, ha továbbra is szükségesnek találta a kivételes állapot fenntartását. Ennek oka elsősorban az, hogy a demokratikus kontroll érvényesítése és a hatalmi ágak egyensúlyának megőrzése érdekében szükséges a különleges jogrend időszakos felülvizsgálata. Emiatt a legtöbb vizsgált állam alkotmányos, illetve törvényi szabályozása nem is ad lehetőséget az elrendeltnél lényegesen hosszabb időbeli hatály meghatározására. Számos országban pedig - így például Csehországban, Szlovákiában, Lettországban, illetve Romániában - a jogszabályi keretek által biztosított leghosszabb határidőre vezettek be különleges jogrendet. A Cseh Köztársaság kormánya harminc napra rendelte el a szükségállapotot, amelyet időről időre felülvizsgáltak, és több alkalommal is meghosszabbítottak. Ugyanígy harmincnapos határidőket határozott meg Románia is a sürgősségi állapot, illetve a riadóállapot vonatkozásában. A spanyol járványkezelés során a kétféle megoldást sajátosan ötvözték, ugyanis első alkalommal mindössze tizenöt napra vezettek be különleges jogrendet, ám azt több alkalommal is meghosszabbították, a kézirat lezárásának időpontjában hatályban lévő rendelkezés szerint pedig a riadókészültség időbeli hatálya Spanyolországban egészen 2021 májusáig tart. Szlovákiában és Lettországban - a járványhelyzet enyhülésére és súlyosbodására reagálva - nem volt folyamatosan hatályban a különleges jogrendi helyzet. A szlovák kormány tavasszal kilencven napra rendelte el a veszélyhelyzetet, ám nem hosszabbította meg, hanem rövid rendes jogrendi időszakot követően a járvány második hullámának kezelése érdekében újból kihirdette azt, immáron negyvenöt napra. (Később pedig - szintén negyvenöt nappal egy alkalommal meg is hosszabbította.) Hasonlóan járt el Lettország is, amely tavasszal két hónapra rendelt el különleges jogrendi állapotot, amelyet még egy alkalommal, szúk egy hónappal ugyan meghosszabbított, ám júniustól egészen novemberig a lett válságkezelés is rendes jogrendi keretek között zajlott. Novemberben azonban újabb veszélyhelyzet kihirdetésére került sor, valamivel több mint kéthónapos időtartamra. Az elrendelt különleges jogrendi helyzetek időbeli hatályát vizsgálva ki kell emelni, hogy Magyarország határozatlan időre vezette be a különleges jogrendi állapotot, amelyhez hasonló megoldást egyedül Kína esetében tapasztalhatunk. Magyarország Alaptörvényének rendelkezése értelmében ugyanis a veszélyhelyzetet elrendelő Kormány jogosult azt megszüntetni, abban az esetben, ha a kihirdetésének feltételei már nem állnak fenn. Ennek megfelelően a járványhelyzet enyhülésével a márciusban bevezetett veszélyhelyzetet Magyarország Kormánya - az Országgyűlés felhívására - nyár elején megszüntette. Hasonlóan azonban Szlovákia és Lettország járványkezeléséhez, a járvány második hullámának hatására novemberben újra különleges jogrend lépett életbe hazánkban is. A különleges jogrendi szituációk elrendelése kapcsán megállapítható, hogy a vizsgált államok - talán egymástól nem teljesen függetlenül - közel egy időben (Magyarországon március 11-én, Csehországban és Lettországban március 12-én, Spanyolországban március 14-én, Finnor- 
szágban, Romániában és Szlovákiában március 16-án, az Egyesült Királyságban pedig március 25-én) vezették be a különleges jogrendi állapotot. Említésre érdemes továbbá, hogy valamennyi vizsgált ország hozott korábban is a koronavírus-járvány kezelésére irányuló intézkedéseket.

Alapvetően megállapítható, hogy ezen államok rendkívül hasonlóan reagáltak az egészségügyi válsághelyzetre, azt szinte azonos keretek között kezelték. A szlovák kormány által márciusban kihirdetett veszélyhelyzet említhető kivételként, azt ugyanis nem általános hatállyal, hanem kizárólag az egészségügyi rendszerre kiterjedően vezették be. A koronavírus-járvány második hulláma idején azonban már Szlovákiában is az egész országra kiterjedt a különleges jogrend hatálya. Ugyancsak valamennyi állam vonatkozásában kijelenthető, hogy korábban nemigen tapasztalt közjogi helyzetet teremtett a különleges jogrend elrendelése, így például Csehországban és Finnországban sem került sor korábban a szükségállapot bevezetésére.

A koronavírus-járványt rendes jogrendi kereteknek megfelelően kezelő államokat egyrészt aszerint csoportosíthatjuk, hogy mely ágazati jogszabályokat hívták segítségül a járványhelyzet leküzdésére, másrészt pedig az alapján oszthatjuk fel ôket, hogy korábban is meglévő vagy a koronavírus-járványra válaszul létrehozott jogintézményeket alkalmaztak. A vizsgált államok közül a legtöbb - így Ausztria, Franciaország, Hollandia, Lengyelország, Németország, Dánia, Norvégia, és Svédország is - a járványügyi, illetve közegészségügyi jogszabályok alapján járt el. Észtország, Litvánia és Olaszország járványkezelése pedig a polgári védelmi, valamint a válságkezelésről szóló jogszabályokra támaszkodott. Az előbbi csoportba tartozó államok sok esetben azonban a koronavírus-járvány leküzdéséhez elégtelennek ítélték meg a jogszabályi kereteket, ezért módosításokat eszközöltek a járvány-, illetve közegészségügyi törvényeiken. Azok mértéke ugyan eltéréseket mutat, de Ausztriában, Németországban, Lengyelországban, Dániában, Norvégiában és Svédországban is elsősorban a különböző korlátozó intézkedések meghozatalának jogalapját biztosítja, valamint növeli a központi kormányzat és az egészségügyi hatóságok hatáskörét. Ezek a módosítások több állam esetében is ideiglenesek, kizárólag meghatározott ideig maradnak hatályban. Így például a dán járványügyi törvény módosítása 2021 márciusában veszti hatályát, Svédországban pedig a módosított rendelkezések csak 2020 nyaráig voltak hatályban. Említésre érdemes Hollandia példája, ahol eleinte mindenfajta módosítás nélkül kizárólag a közegészségügyi törvény rendelkezéseire alapozták az intézkedéseket, ám később - a különleges jogrendi állapot elrendelését hiányoló, a demokratikus kontroll meglétét, valamint az alapjogok korlátozásának alkotmányosságát megkérdőjelező - kritikák hatására mégis módosították a jogszabályt. Kiemelendő továbbá a franciaországi járványkezelés, ahol a szükségállapotnak egy új formáját rögzítették a közegészségügyi törvénykönyvben. Az egészségügyi szükségállapot olyan egészségügyi katasztrófa esetén alkalmazható, amely jellegénél és súlyosságánál fogva veszélyezteti a lakosság egészségét. Ez a jogintézmény azonban ideiglenesen lett a kódexbe bevezetve, az legkésőbb 2021. április 1-ig tartható fenn. Az egészségügyi szükségállapotot 2020. március 24-tôl két hónapos időtartamra hirdették ki az ország egész terü- 
letére, később pedig több alkalommal meghosszabbították. Franciaországban tehát egy különleges jogrendi állapotnak ugyan nem minősülő, mégis kivételesnek titulálható, ráadásul újonnan, a koronavírus-járványra válaszul megalkotott helyzetet vezettek be. Hasonlóan járt el - a jogintézmény újdonságától eltekintve - Lengyelország is, ahol az egészségügyért felelős miniszter rendeletével előbb járványveszélyt, később pedig járványállapotot hirdetett. A polgári védelmi jogszabályok alapján eljáró államok vonatkozásában szintén elmondható, hogy bár nem került sor különleges jogrend bevezetésére, de rendkívüli jelleggel bíró válságkezelési intézkedéseket foganatosítottak. Így például Észtországban - a kifejezetten különleges jogrend elrendelését nem igénylő válsághelyzetek egységes kezelése érdekében megalkotott - veszélyhelyzeti törvény alapján veszélyhelyzetet hirdettek ki, amely egyszeri meghosszabbítással valamivel több mint két hónapig volt hatályban, később pedig a sokkal enyhébb válsághelyzeti állapot kategóriája került bevezetésére. Az Olasz Köztársaságban pedig a Polgári Védelmi Kódexben szabályozott nemzeti szintú szükségállapotot hirdettek ki, időbeli hatályként a rendelkezés napjától számított hat hónapot megjelölve. Azt azonban két alkalommal is meghosszabbították, így - a kézirat lezárásakor hatályban lévő jogszabályok alapján - elmondható, hogy a szükségállapot Olaszországban egy teljes évig hatályban marad.

A koronavírus-járvány kezelésének jogi kereteit nyilvánvalóan determinálta az államok különleges jogrendi szabályozása. A járványhelyzet során a rendes jogrendi keretek szerint eljáró államok között találunk olyat, ahol fel sem merülhetett a különleges jogrend elrendelése, hiszen nem is találunk békeidejû különleges jogrendi szituációt, kizárólag háborús rendelkezést (például Olaszország, Svédország). Vannak államok, ahol bár a hadiállapoton kívül más különleges jogrendi kategóriák is rögzítésre kerültek, ám a koronavírus-járvány nem illeszkedik azok tényállásába (például Észtország, Franciaország). Illetőleg vannak olyan államok is, ahol hiába beszélhetünk elrendelhető különleges jogrendi helyzetről, annak kihirdetésére - komoly közjogi vitákat kiváltva - mégsem került sor (például Hollandia, Lengyelország).

Érdemes megemlíteni, hogy a különleges és rendes jogrendi szabályok kombinációjára is találunk példát. Szlovákiában a kormány még a veszélyhelyzet elrendelése elött az egész országra kiterjedó hatállyal rendkívüli helyzetet hirdetett, amely jogintézmény nem minősül hagyományos értelemben vett különleges jogrendi esetkörnek, részletszabályait pedig a polgári védelmi, illetve a közegészségügyi törvények tartalmazzák. Ellentétben a különleges jogrendi állapottal, a rendkívüli helyzet Szlovákiában megszakítás nélkül hatályban volt. Magyarországon pedig a veszélyhelyzet nyári megszüntetésével egyidejúleg, az egyes intézkedések és korlátozások fenntartásának indokoltsága miatt járványügyi készültséget hirdettek ki, amelynek egyes rendelkezései a veszélyhelyzet újbóli bevezetését követően is hatályban maradtak.

Habár jelen könyv részletesen foglalkozik az Egyesült Államok és Kína különleges jogrendi szabályozásával, valamint a koronavírus-járvány kezelésével, azok kevéssé hasonlít- 
hatók az eddig tárgyalt államok megoldásaihoz. Az Egyesült államok egészségügyért felelős minisztere már január végén közegészségi veszélyhelyzetet hirdetett, 2020. március 13-án pedig az elnök kihirdette az országos veszélyhelyzetet is. Tehát különleges jogrendi helyzetet vezettek be a járványhelyzet kezelése érdekében, ám az USA különleges jogrendi modellje a szabályozás koncepciója és decentralizációja, az ultima ratio jelleg hiánya, valamint az elrendelés határozatlan időtartama miatt jelentősen eltér a hazai - és a legtöbb európai - különleges jogrendi keretektől. Ezzel szemben Kínában szükségállapot helyett a különleges jogrendi szituációnak nem minősülő - a kifejezetten az alacsonyabb szintú válsághelyzetek kezelése érdekében elfogadott, veszélyhelyzeti intézkedésekről szóló törvényben rögzített veszélyhelyzet kategóriáját vezették be. A négyfokozatú kategóriarendszer legsúlyosabbnak minősülő első szintjét, az úgynevezett különösen komoly veszélyhelyzetet rendelték el határozatlan idôtartamra, időbeli korlát nélkül, azonban idővel enyhítették az intézkedéseket. Emellett megállapítható, hogy a kínai jogrendszer - köszönhetően annak, hogy számos jogszabálya tartalmaz járványkezelést segítő kivételes intézkedést - fel van készülve egy esetleges járványhelyzet bekövetkezésére.

\section{A koronavírus-járvány kezelése érdekében megvalósuló rendeleti kormányzás, és a parlament kontrollfunkciója}

A koronavírus-járvány terjedésének megakadályozása és az egészségügyi válsághelyzet leküzdése tehát valamennyi államtól gyors és hatékony reakciót követelt meg, amit a vizsgált államok leginkább a kormányzat hatáskörének kibővítésével, illetve mozgásterének megnövelésével láttak megvalósíthatónak. A különleges jogrendi állapotot elrendeló államok vonatkozásában - tekintve, hogy az általánostól eltérő szabályok intézményesítésével a jogalkotó célja a hatalommegosztás rendjének átalakítása, illetve meghatározott szervek számára többletjogosítványok biztosítása ${ }^{4}$ - ez a rendeleti kormányzás eszközének alkalmazásával valósul meg. Így Csehországban, Magyarországon, Romániában, Szlovákiában, Finnországban, Lettországban, valamint Spanyolországban a különleges jogrendi szituáció kihirdetésével egyidejúleg felhatalmazták a kormányt, hogy rendeleti úton alkossa meg a szükséges intézkedéseket. Az Egyesült Királyságnak a koronavírus-járvány kezelése érdekében megalkotott törvénye is a rendeleti kormányzás kereteit kívánta megteremteni. A kormány jogalkotói hatáskörrel való felruházása kapcsán az jelent komolyabb különbséget, hogy egyes országokban - a kormány mint kollektív testület mellett - meghatározott miniszterek kiemelt szerepet kapnak a járványkezelés során. Csehországban és Romániában az egészségügyért felelős miniszter, Spanyolországban pedig - az egészségügyi miniszter mellett -

4 Csink, 2017, 13-14. o. 
a honvédelmi, a belügyi, illetve a közlekedési tárca vezetője alanya - a szükséges rendkívüli intézkedések kibocsátása révén - a rendeleti kormányzásnak.

A különleges jogrendet be nem vezető államok vonatkozásában is megfigyelhető, hogy a kormánynak vagy valamely tagjának kivételes jogköröket biztosítottak a hatékony járványkezelés érdekében. Ez a polgári védelmi jogszabályok alapján eljáró államok vonatkozásában különösen igaz. Észtországban a járványkezelést például a kormány által kijelölt miniszter irányítja, aki jogosult a járványkezelés érdekében szükséges utasítások kibocsátására. Olaszországban - bár a szükségállapot során is van lehetőség az intézkedések speciális rendelkezésekkel való összehangolására - a járványhelyzet kezelésének végül mégsem a polgári védelmi szabályok, hanem a sürgősségi rendeleti kormányzás intézményének megfelelően kibocsátott törvényerejû̉ rendeletek adtak keretet, amelyek értelmében a koronavírus-járvány kezelése és leküzdése érdekében a miniszterelnök rendeletében - az egészségügyért felelős miniszter javaslata alapján - sürgős intézkedéseket bocsáthat ki.

A járvány-, illetve közegészségügyi törvényeket alkalmazó államok kivétel nélkül kisebb-nagyobb módosításokat eszközöltek a vonatkozó jogszabályaikon. Ausztriában és Dániában is a törvények célzott módosítása teremtett jogalapot a kormány kivételes rendelkezéseinek kibocsátásához. Németországban a módosítások hatására - a szövetségi államok hatásköreinek sérelme nélkül - a Szövetségi Egészségügyi Minisztérium kap felhatalmazást valamennyi, a járványhelyzet szempontjából releváns intézkedés meghozatalára. Lengyelországban a korábban is meglévő járványveszély és járványállapot kategóriáit módosították úgy, hogy azok vonatkozásában rendeletalkotási jogkörrel ruházták fel a Minisztertanácsot. Ugyan a svéd járványkezelést alapvetően a Közegészségügyi Ügynökség ajánlásai határozzák meg, azonban a gyorsabb fellépés biztosítása érdekében - ideiglenes hatállyal - kiterjesztették a kormány jogalkotó hatáskörét, rögzítve, hogy ha az a koronavírus-járvány kezelése érdekében szükséges, és nem várható a parlament jogalkotása, a kormány rendeletet alkothat. A Franciaországban újonnan létrehozott és be is vezetett egészségügyi szükségállapot során - az egészségügyért felelős miniszter javaslata alapján - a miniszterelnök jogosult rendeletével meghozni a koronavírus-járvány leküzdéséhez szükséges rendelkezéseket. Hollandia járványkezelése a tekintetben tér el a többi vizsgált államétól, hogy ott eleinte a közegészségügyi törvény mindenfajta módosítása nélkül az egészségügyi miniszter irányította a koronavírus-járvány elleni védekezést, amivel egyidejủleg - a biztonsági körzetekról szóló törvény alapján - a biztonsági körzetek vezetői kaptak felhatalmazást arra, hogy - az egészségügyi miniszter iránymutatása mellett - átvegyék a védekezés megszervezésével kapcsolatos, a polgármestereket megillető hatáskörök gyakorlását. Később azonban - a járványkezelést ért kritikák hatására - módosították a közegészségügyi törvényt, amely alapján miniszteri rendeletekben rögzítik a járványkezeléshez szükséges intézkedéseket. Norvégiában már a kormány rendkívüli felhatalmazását biztosító törvényjavaslat elfogadása előtt kritikát fogalmaztak meg az előkészítő munka elégtelensége és a megfelelő demokratikus kontroll hiánya kapcsán, így végül az elfogadott törvényszöveg szűkebb felhatalmazást biztosított a kormánynak, amely mellett a király is jelentős hatásköröket gyakorolhat. 
Tekintettel arra, hogy a koronavírus-járvány okozta válsághelyzet leküzdése érdekében a végrehajtó hatalom törvényhozói jogosítványokat kapott, érdemes áttekinteni, hogy a hatalmi ágak egyensúlyának biztosítása érdekében miként érvényesül a parlamenti kontrollfunkció. A különleges jogrendet bevezető államok esetében a garanciális szabályok több típusát különböztethetjük meg. Csehország és Lettország esetében a különleges jogrendi állapot fennállásához elengedhetetlen a parlament támogatása. Előbbi esetében a parlament alsóháza, a képviselőház utólagosan megsemmisítheti a kormány különleges jogrend bevezetésére irányuló döntését, az elrendelt szükségállapot meghosszabbításához pedig - amely a koronavírus-járvány kezelése kapcsán meg is valósult - szükség van a képviselőház előzetes jóváhagyására. Ezen túlmenően a parlament a kihirdetett szükségállapotot a meghatározott időtartam lejártát megelőzően bármikor megszüntetheti. Más államok vonatkozásában - így például Finnországban és Magyarországon - a különleges jogrend során kibocsátott rendeletek megerősitésében valósul meg a törvényhozó hatalom ellenőrző szerepe. A magyar különleges jogrendi szabályozás értelmében a kormányrendeletek hatályának meghosszabbításához szükséges a parlamenti támogatás, a koronavírus-járvány kezelése során pedig ennek érdekében az Országgyuulés törvényben rögzítette azt, hogy a meghozott rendeletek csak a veszélyhelyzet megszúnésével veszítik el hatályukat. Az Egyesült Királyságban a különleges jogrendet bevezetô törvény vitája során a kormány ígéretet tett arra, hogy beszámol a parlamentnek a meghozott intézkedésekről, így lehetőség nyílik a kivételes rendelkezések megvitatására. Bár nem minősül klasszikus különleges jogrendi kategóriának, itt érdemes megemlíteni az Olasz Köztársaságban a járványhelyzet során alkalmazott sürgősségi rendeleti kormányzás vonatkozásában érvényesülő parlamenti kontrollt. A törvényerejü rendeleteket ugyanis késedelem nélkül be kell nyújtani a parlamentnek, amely azokat hatvan napon belül törvénnyé alakíthatja, vagy hatályon kívül helyezheti. Komoly vitákat váltott ki, hogy a koronavírus-járvány kezelése érdekében kibocsátott törvényerejû́ rendeletek a miniszterelnök hatáskörébe utalták a kivételes intézkedések meghozatalát, ezáltal pedig a parlament ellenőrzési jogköre kevésbé érvényesült.

Azon államok vonatkozásában, ahol rendes jogrendi keretek között reagáltak az egészségügyi válsághelyzetre, kevésbé releváns kérdés a parlament ellenőrző funkciójának érvényesülése. Ezekben az országokban a kivételes jogosítványok és intézkedések törvényi rendelkezésen alapulnak, egyes államok kapcsán azonban így is rögzítettek bizonyos többletgaranciákat. Franciaországban és Lengyelországban ezt a kormány tájékoztatási kötelezettsége jelenti. Előbbi államban a kormány köteles valamennyi, az egészségügyi szükségállapottal kapcsolatos intézkedéséról haladéktalanul tájékoztatni a parlament mindkét házát, utóbbiban pedig havonta tesz jelentést a Minisztertanács a szenátusnak és a képviselóháznak. A svédországi szabályozás ennél erősebb kontrollfunkciót biztosít a parlamentnek. A svéd kormány által kibocsátott rendeleteket ugyanis haladéktalanul be kell nyújtani felülvizsgálatra a parlamentnek, amely azt törvénnyel módosíthatja, vagy akár hatályon kívül is helyezheti. Hasonló szerepe van a holland parlamentnek, ahol a törvényhozás egy héten belül dönt a kormány rendeletének megerősítéséről, amely szabálytól csak sürgető körülmény fennállta esetén lehet eltérni, a parlament azonban ez 
esetben is kontrollt gyakorol a megalkotott rendeletek felett. E szabályok rögzítésére viszont csak a demokratikus kontroll hiányát megfogalmazó kritikák hatására került sor.

Az európai járványkezelési modellekhez kevésbé illeszkedő megoldások közül az Egyesült Államokban szövetségi törvények határozzák meg a korlátozó rendelkezéseket, illetve segélyintézkedéseket, a kínai veszélyhelyzeti szabályozás pedig a helyi szintû́ kormányzatot bízza meg - a veszélyhelyzeti tervben foglaltaknak megfelelő - veszélyhelyzet felmérésére és kezelésére irányuló intézkedések meghozatalával.

A vizsgált államok járványkezelési megoldásainak összevetéséből kitűnik, hogy annak során - függetlenül attól, hogy az különleges jogrendi vagy rendes jogrendi keretek között valósult meg - a kormányt vagy annak meghatározott tagjait ruházták fel kivételes hatáskörrel, amely elsősorban különböző korlátozó rendelkezések kibocsátásában öltött testet.

\section{A koronavírus-járvány kezelése során bevezetett alapjog-korlátozás, valamint a járványkezeléssel összefüggésben felmerült közjogi-politikai viták}

Míg az alapvető jogok békeidőben történő korlátozása alkotmányjogi szempontból aggályosnak tekinthető, addig az állam normál müködését veszélyeztető állapotban - így jelen esetben a koronavírus-járvány következtében elóálló egészségügyi válsághelyzetben - a hatékony járványkezelés érdekében az alapjogok korlátozhatók vagy akár fel is függeszthetők, így azok szükségszerúen csorbát szenvednek. Függetlenül attól, hogy az e munka által elemzett országok a koronavírus-járvánnyal szembeni védekezés érdekében bevezettek-e különleges jogrendet, avagy ennek mellôzésével rendes jogrendi keretek között igyekeztek kezelni a járványhelyzetet, megállapítható, hogy mindegyik vizsgált országban sor került az alapjogok bizonyos szintû́ korlátozására a járványkezelésre felhatalmazott állami szervek vagy személyek által.

Az alapjogokat korlátozó rendkívüli intézkedések vonatkozásában elsőként azt szükséges rögzíteni, hogy mely alkotmányos érték védelme vagy alapvető jog érvényesülése érdekében került sor más alapjogok korlátozására. A koronavírus-járvány jellegéből is adódik, hogy az emberi élet és egészség védelme tette szükségessé az alapjogok rég nem látott, jelentős mértékú korlátozását világszerte. Az alapjogok korlátozásának alkotmányosságához ugyanakkor nemcsak az alkalmassági teszt, hanem az arányossági és szükségességi teszt elvégzése is szükséges. Ez alapján alapvető jogot korlátozni - a legitim cél megjelölésén túl - csak a feltétlenül szükséges mértékben, az elérni kívánt céllal arányosan, és az alapvető jog lényeges tartalmának tiszteletben tartásával lehet. Az alapjogok korlátozásának további, tartalmi korlátjaként jelentkezik az abszolút jogok korlátozásának tilalma. Habár az alapjogok korlátozására irányuló rendkívüli intézkedések a vizsgált országokban számos esetben közjogi-politikai vitákat generáltak, azok jogszerűsége többségében megfelelt az alapjogok korlátozásának alkotmányosságához 
füződő nemzeti és nemzetközi sztenderdeknek egyaránt. Az elemzett országok sorában kivételként egyedül Kína említhetô, ahol az alapvető jogok korlátozása nem a demokratikus és jogállami elveknek feleltethetô meg, így ott az alapjogok meglehetősen csekély védelmet élveznek. Ez okból kifolyólag Kínában a koronavírus-járvány kezelése érdekében bevezetett intézkedések vonatkozásában az alapjog-korlátozás fentebb ismertetett szabályai kevéssé érvényesülnek.

Az emberi élet és egészség, azaz a közegészség védelme mint legitim cél érdekében bevezetett korlátozó intézkedések az alapjogok széles körét érintették. Jelen munka terjedelmi korlátait meghaladná az egyes országok által bevezetett korlátozó intézkedések taxatív jellegú felsorolása, ezért e ponton csupán azokra az alapjogokra kívánunk utalni, amelyek az elemzett országok szinte mindegyikében korlátozásra kerültek a járványkezelés során. Ezen alapjogok a következők:

— a személyes szabadsághoz való jog;

- a mozgásszabadság és a tartózkodási hely szabad megválasztásának joga;

- gyülekezési jog;

— a vállalkozáshoz, illetve az üzleti tevékenység végzéséhez füződő jog;

- az oktatáshoz való jog.

Habár a korlátozó intézkedések az emberek alapvető jogait egyenlő mértékben és általánosan érintették, ugyanakkor azok hatással voltak egyes társadalmi csoportok külön jogaira is. E körön belül megemlítendők különösen az idősek, valamint a tanköteles korú gyermekek, hiszen e két társadalmi csoport vonatkozásában több ország is speciális, ugyanakkor egymáshoz hasonló szabályokat léptetett életbe (például az idősek vásárlási idősávjának bevezetése vagy a digitális távoktatásra történő átállás az oktatásban stb.).

Ami az alapjogok korlátozásának mértékét illeti, megállapítható, hogy a vizsgált államok által elrendelt korlátozások intenzitása között számottevő különbség nem fedezhető fel, egy kivételtől eltekintve. E kivételt Svédország jelenti, amely egy különutas válságkezelési stratégiát alkalmazott, amit számos kritika ért annak unortodox jellege miatt. Svédországban - a vizsgált országokkal ellentétben - az alapjogok korlátozására csak nagyon szúk körben került sor. A széles körú alapjog-korlátozás elmaradásának hátterében az állt, hogy a svéd járványkezelési modell az alapvető jogok korlátozása helyett az állampolgároknak szóló, jogilag nem kötelező erejú ajánlások kibocsátásában látta a járvány hatékony kezelésének módját.

A vizsgált államok szabályozásában további hasonlóság figyelhető meg a tekintetben, hogy az alapjog-korlátozó intézkedések bevezetésére és hatályon kívül helyezésére, valamint azok szigorítására és enyhítésére hozzávetőlegesen egy időben került sor. Az első korlátozó intézkedések elrendelésére a legtöbb vizsgált államban a koronavírus-járvány megjelenésének időpontjában, 2020 márciusában került sor, míg azok enyhítése vagy eltörlése május-júniusban történt meg. A korlátozások ismételt bevezetésére vagy szigorítására pedig a koronavírus-járvány második hullámával egy időben, tehát október-november hónapokban került sor. Ezek a megállapítások ugyanakkor csak a vizsgált európai országokra vonatkoznak, hiszen az Egyesült Államokban, 
de különösen Kínában, a koronavírus megjelenésének helyén a járvány lefolyása, ezáltal pedig a korlátozó intézkedések bevezetése és visszavonása más idősíkon mozgott.

Érdemes röviden említést tenni azokról a szabályozási sajátosságokról, amelyek a vizsgált országok államszerkezetéből adódnak. Habár az államszerkezet alapvetően kétféle, föderatív vagy unitárius lehet, azonban egyes szakirodalmak a kettő közötti átmenetként nevesítik a regionális berendezkedésú államokat is, mint harmadik kategóriát. ${ }^{5}$ Ezzel összefüggésben, a vizsgált országok vonatkozásában azt látjuk, hogy a föderatív berendezkedésû (Ausztria, Németország, Egyesült Államok), valamint a regionális berendezkedésú (Egyesült Királyság, Olaszország, Spanyolország) országokban a járványkezeléssel összefüggő döntések meghozatala és végrehajtása megoszlik a központi/szövetségi kormányzat, valamint a tagállamok/tartományok/régiók között. Mindez az alapjogok korlátozása kapcsán azért bír jelentőséggel, mert azt látjuk, hogy e nem unitárius berendezkedésû államokban a járványkezelés során meghozott központi kormányzati alapjog-korlátozó intézkedések mellett a bizonyos szintû autonómiát élvező területi egységek is kibocsátanak olyan intézkedéseket, amelyek adott esetben alapjogokat korlátoznak. Az ilyen típusú korlátozó intézkedések természetesen nem lehetnek ellentétesek a központi kormányzat által elrendelt korlátozásokkal, és azok a gyakorlatban általában kiegészítik, illetve szigorítják a központilag meghozott intézkedéseket - mindez pedig nem ritkán konfliktust generál a központi kormányzattal.

Az egészségügyi válsághelyzet kezelésével összefüggésben - függetlenül attól, hogy bevezetésre került-e különleges jogrend, vagy sem - élénk és intenzív közjogi, valamint politikai viták alakultak ki a vizsgálat alá vont államok szinte mindegyikében. E ponton fontosnak tartjuk rögzíteni, hogy e viták sok esetben csak látszólag szólnak a rendkívüli felhatalmazással kapcsolatos jogi kérdésekről, azok a gyakorlatban sokszor tisztán csak politikai természetúek. Jelen munkának nem célja, hogy taxatív felsorolást adjon a járványügyi veszélyhelyzet kapcsán kibontakozó viták tárgyáról, e ponton csupán utalni kívánunk azokra a jogilag releváns témakörökre, amelyek a vizsgált országokban jelentős közjogi-politikai viták alapját képezték, amelyek a következők:

- a különleges jogrend bevezetésének indokolatlansága, avagy a bevezetés hiánya;

- a különleges jogrend időtartamával, valamint annak meghosszabbításával kapcsolatos kérdések;

— az alapjogok aránytalan és szükségtelen mértékú korlátozása;

- a rendkívüli felhatalmazással bíró személy vagy szerv túlzott hatalma, valamint alkotmányellenes és a jogállamiság kritériumait sértő intézkedései;

— a törvényhozó szervek korlátozott mozgástere;

- a nem unitárius államok vonatkozásában a központi kormányzat és az autonómiát élvező területi egységek közötti hatásköri viták a korlátozó intézkedések kapcsán.

5 Trócsányi-Schanda, 2014, 39-41. 0. 
A járványkezelés során megalkotott rendkívüli intézkedések legitimációja feletti elméleti viták hamar gyakorlati formát öltöttek, mégpedig a bírósági út igénybevétele által. Ha eltekintünk azoktól a vitáktól, amelyeket tisztán politikai célok és érdekek vezéreltek, és kizárólag a jogilag releváns ügyekre fókuszálunk, akkor azt látjuk, hogy számos országban, ahol különleges jogrend került bevezetésre, bár a törvényhozó hatalom mozgástere és kontrollfunkciója jelentôsen leszúkkült, de ezzel párhuzamosan a nemzeti alkotmánybíróságok, legfelsőbb bíróságok, rendes és közigazgatási bíróságok, sőt az ombudsmanok szerepe és felelőssége megnőtt a korlátozó intézkedések ellenőrzése tekintetében. Számos vizsgált országban (például Ausztriában, Csehországban, Franciaországban, Romániában stb.) a bíróságok korrigálták, adott esetben pedig meg is semmisítették a rendeleti kormányzás felhatalmazottja által megalkotott rendkívüli intézkedéseket. De találunk olyan példát is, ahol bírósági út igénybevétele nélkül, szimplán a társadalmi nyomás és a politikai ellenzék kritikája következtében került sor a járványkezelési stratégia módosítására. Erre jó példa Hollandia, ahol e viták hatására a kormány benyújtott egy törvénymódosítási javaslatot, amelynek célja az volt, hogy a demokratikus kontroll és a jogállamiság kritériumainak megfelelő jogszabályi keretet teremtsen a járvány második hulláma elleni védekezés során meghozandó intézkedésekhez.

\section{4. Összegzés}

A vizsgálat alá vont országok szabályozásának áttekintését követően megállapíthatjuk, hogy a koronavírus-járvány miatt azonos kihívásokkal szembesülő államok rendkívül hasonló intézkedéseket alkalmaztak a járvány leküzdése érdekében, azonban azok jogszabályi keretei számos ponton eltérést mutatnak.

A vizsgált országokat egyrészt az alapján csoportosíthatjuk, hogy a járvány elleni védekezés érdekében különleges jogrend bevezetésére sor került-e, avagy sem az adott országban. Előbbi kategóriába tartozik Magyarország, Csehország, Szlovákia, az Egyesült Államok, az Egyesült Királyság, Finnország, Lettország, Románia és Spanyolország. Ennek megfelelően a többi vizsgált államban rendes jogrendi keretek között valósult meg a járványhelyzet kezelése. Az utóbbi kategóriába tartozó országokat ugyanakkor tovább csoportosíthatjuk aszerint, hogy milyen típusú ágazati jogszabály(ok) alapján valósult meg a járvánnyal szembeni védekezés. Egyes országok a járványügyi és közegészségügyi törvényeik (Ausztria, Franciaország, Hollandia, Lengyelország, Németország, Dánia, Norvégia, Svédország), míg más országok a polgári védelmi, valamint válságkezelési törvényeik alapján (Észtország, Kína, Litvánia, Olaszország) szabályozták a járvánnyal szembeni védekezés jogi kereteit. A járvány elleni védekezés érdekében elrendelt különleges jogrendi esetkörök, illetve a különleges jogrendnek nem minősülő rendkívüli szituációk időbeli hatálya pedig rendkívül változatos képet mutat a vizsgált országok szabályozásában. 
A gyors és hatékony védekezés érdekében a különleges jogrendet elrendelő országokban egyúttal rendeleti kormányzás bevezetésére került sor, amelynek általános felhatalmazottja a vizsgált országok esetében a kormány. Ugyanakkor egyes, különleges jogrendet bevezető országok (Csehország, Egyesült Királyság, Románia, Spanyolország) esetében azt látjuk, hogy a kormány mellett egyes miniszterek (általában az egészségügyért felelős miniszter) is kiemelt szerepet kapnak a járványkezelés során, azáltal, hogy felhatalmazással rendelkeznek a szükséges rendkívüli intézkedések kibocsátására. A kormányzat mozgásterének növelése ugyanakkor nem csak a különleges jogrendet bevezető országokban figyelhető meg. Az egészségügyi válsághelyzetet rendes jogrendi keretek között kezelő országokban is megfigyelhető az a tendencia, hogy a kormánynak vagy valamely tagjának kivételes jogköröket biztosítottak a hatékony járványkezelés érdekében.

A különleges jogrendet - és ezáltal rendeleti kormányzást - bevezető országokban a végrehajtó hatalom hatáskörének kibővítése számos esetben a törvényhozó hatalom kontrollfunkciójának bizonyos mértékú korlátozását eredményezte. Mindez azonban egyik vizsgált állam vonatkozásában sem eredményezte a nemzeti parlamentek ellenőrző tevékenységének teljes kiiktatását. Azokban az országokban, ahol rendes jogrendi keretek között reagáltak a koronavírus-járványra, kevésbé releváns kérdés a törvényhozó szervek ellenőrző funkciójának érvényesülése, hiszen ezekben az országokban a kivételes jogosítványok és intézkedések törvényi rendelkezésen alapulnak, sốt egyes államokban többletgaranciát kaptak a nemzeti parlamentek a kormányzati válságintézkedések ellenőrzése terén. (Franciaországban és Lengyelországban a kormánynak a parlament irányába fennálló tájékoztatási kötelezettsége, míg Hollandiában és Svédországban a parlament válságintézkedéseket megerősítő jogosítványa által.)

A koronavírus-járvány okozta egészségügyi válsághelyzet leküzdése érdekében a vizsgált államok mindegyike élt az alapjog-korlátozás lehetőségével. Az emberi élet és egészség, vagyis a közegészség védelme érdekében bevezetett korlátozó intézkedések az alapjogok széles körét érintették. A járvány jellegéből adódik, hogy a rendkívüli helyzet megfelelő kezelése érdekében különösen a személyes szabadsághoz való jog, a mozgásszabadság és a tartózkodási hely szabad megválasztásának joga, a gyülekezési jog, a vállalkozás szabadsága, valamint az oktatáshoz való jog került korlátozásra. Az elemzett országok által korlátozott szabadságjogok köre, korlátozásuk intenzitása és formája közel azonos, függetlenül attól, hogy különleges jogrendi szituációt vezettek-e be, vagy sem. Megállapítható továbbá az is, hogy az egészségügyi válsághelyzet kezelésével összefüggésben a vizsgált országok szinte mindegyikében komoly közjogi-politikai viták alakultak ki.

\section{Irodalomjegyzék}

Alexandre, Z., Del Monte, M., Eckert, G., Kotanidis, S., LANGova, V., Rakovska, V. (2020) States of Emergency in Response to the Coronavirus Crisis: Situation in Certain Member States IV. [Online]. Elérhető: www.europarl.europa.eu/RegData/etudes/BRIE/2020/652002/EPRS_ BRI(2020)652002_EN.pdf (Letöltve: 2020. december 15.) 
Atanassov, N., Dalli, H., Dumbrava, C., Eckert, G., Jurviste, U., Radjenovic, A., Voronova, S. (2020) States of Emergency in Response to the Coronavirus Crisis: Situation in Certain Member States II. [Online]. Elérhető: www.europarl.europa.eu/RegData/etudes/ BRIE/2020/651914/EPRS_BRI(2020)651914_EN.pdf(Letöltve: 2020. december 15.)

Bentzen, N., Boström, A., Del Monte, M., Odink, I., Prpic, M., Tuominen, M. (2020) States of Emergency in Response to the Coronavirus Crisis: Situation in Certain Member States III. [Online]. Elérhető: www.europarl.europa.eu/RegData/etudes/BRIE/2020/651972/EPRS_ BRI(2020)651972_EN.pdf(Letöltve: 2020. december 15.)

Binder, K., Crego, M. D., Eckert, G., Kotanidis, S., Manko R., Del Monte, M. (2020) States of Emergency in Response to the Coronavirus Crisis: Situation in Certain Member States. [Online]. Elérhető: www.europarl.europa.eu/RegData/etudes/BRIE/2020/649408/EPRS_ BRI(2020)649408_EN.pdf (Letöltve: 2020. december 15.)

CAmeron, I., Jonsson Cornell, A. (2020) 'Fredstida kriser i en konstitutionell kontext en komparativ analys och en försiktig framåtblick för Sveriges del', Svensk Juristtidning, 2020/10, 1173-1190. o.

Csink, L. (2017) 'Mikor legyen a jogrend különleges?', Iustum Aequum Salutare, 13(4), 7-16. o.

Desmet, C. A. (2020): "The Legal Concept of "State of Emergency": A Comparison Between Romania and Other European Countries', Acta Universitatis Danubius Juridica, 16 (1), 79-88. o.

Golia, A. Jr., Hering, L., Moser, C., Sparks, T. (2020) 'Constitutions and Contagion. European Constitutional Systems and the COVID-19 Pandemic', Max Planck Institute for Comparative Law and Internatial Law, Research Paper Series, 42/2020

Guasti, P. (2020) 'The Impact of the COVID-19 Pandemic in Central and Eastern Europe. The Rise of Autocracy and Democratic Resilience', Democratic Theory, 7(2), 47-60. o.

Hegedős, S., KarÁcsony, A., Monostori, M. (2020) 'Alkotmányosság és járványveszély', Jogelméleti Szemle, 2020/4, 28-42. 0.

HoJNYÁk, D., UngVÁRI, Á. (2020) 'Az Európai Unió egyes tagállamainak koronavírusjárványra adott válasza, különös tekintettel a vizsgált államok által bevezetett különleges jogrendi szabályozásra', Miskolci Jogi Szemle, 15(1), 122-138. o.

HoJnYÁk, D., UngVÁRI, Á. (2021) 'A Visegrádi Együttműlködés országainak koronavírusjárványra adott válasza', Iustum Aequum Salutare, (17)1, 305-323. o.

TRócsáNYI, L., SCHANDA, B. (2014) Bevezetés az alkotmányjogba-AzAlaptörvényés Magyarország alkotmányos intézményei. Budapest: HVG-ORAC

Venice Commission (2020) Interim Report on the Measures Taken in the EU Member States as a Result of the Covid-19 Crisis and Their Impact on Democracy, the Rule of Law and Fundamental Rights (Opinion No. 995/2020) [Online]. Elérhető: www.venice.coe.int/webforms/documents/ default.aspx?pdffile=CDL-AD(2020)018-e (Letöltve: 2020 . december 15.) 